\title{
GENETIC VARIABILITY AND YIELD COMPONENTS OF YARD LONG BEAN \\ (Vigna unguiculata var. sesquipedalis L.)
}

\author{
GENETSKA VARIJABILNOST I SASTAVNI DIJELOVI \\ DUGAČKOG GRAHA
}

(Vigna unguiculata var. sesquipedalis L.)

\section{Zakia Sultana, Nahid Ahmed, Mohammad Saiful Islam, Md. Abdur Rahim}

\begin{abstract}
Yard long bean (Vigna unguiculata var. sesquipedalis L.) is one of the important leguminous vegetables in Bangladesh. However, yield of this vegetable is much lower in Bangladesh compared to other yard long bean growing countries. Therefore, it is crucial to improve the yield of this vegetable. In the present study, genetic variability, heritability, character association and genetic diversity were evaluated on randomized complete block design with three replications among seven-yard-long bean genotypes. The genotypes were significantly variable for the studied characters. High genotypic and phenotypic coefficient of variation was observed in number of pods per plant and pod yield per plant. Accordingly, high heritability together with high genetic advance in percent of mean was observed in number of pod per plant, pod diameter and hundred seed weight. The correlation studies revealed that pod yield per plant showed significant positive correlation with number of seed per pod, number of pods per plant while significantly negative correlation with days to marketable harvest at both genotypic and phenotypic level. Path analysis revealed days to first flowering, days to maturity, number of pods per plant, pod weight and number of seeds per pod had direct positive effect on pod yield per plant. The studied genotypes were clustered into 3 groups with highest of inter-cluster distance between cluster I and III while lowest between cluster II and III. The genotypes of cluster I exhibited higher mean performance while lower in cluster III for important traits including pod yield per plant.
\end{abstract}

Key words: genetic variability, heritability, yield, yard long bean 
Zakia Sultana et. al.: Genetic variability and yield components of yard long bean (Vigna unguiculata var. sesquipedalis L.)

\section{SAŽETAK}

Dugački grah (Vigna unguiculata var. sesquipedalis L.) jedna je od važnih mahunarki u Bangladešu. Međutim, prinos ovog povrća je mnogo niži u Bangladešu u usporedbi s drugim zemljama gdje se uzgaja ovo povrće. Stoga je bitno poboljšati prinos ovog povrća. U ovom radu procjenjivani su genetska varijabilnost, heritabilnost, karakterna povezanost i genetska raznolikost na slučajnom blok dizajnu. Genotipovi su značajno varirali u proučavanim značajkama. Visoki genotipski i fenotipski koeficijent varijacije proučavani su na broju mahuna po biljci i prinosu mahuna po biljci. U vezi s time primijećena je visoka heritabilnost $\mathrm{i}$ visoko genetsko poboljšanje u postotnom prosjeku u broju mahuna po biljci, promjeru mahune i težini sto sjemenki. Proučavanje korelacije otkrilo je da je prinos mahune po biljci pokazao značajnu pozitivnu korelaciju s brojem sjemenki po mahuni i brojem mahuna po biljci dok je korelacija s danima do berbe za tržište bila značajno negativna na genotipskoj i fenotipskoj razini. Analiza je otkrila da su dani do cvjetanja, dani do dozrijevanja, broj mahuna po biljci, težina mahune i broj sjemenki po mahuni imali izravno pozitivno djelovanje na prinos mahune po biljci. Proučavani genotipovi svrstani su u tri skupine s najvećom udaljenosti između klastera I i III dok je najniža bila između klastera II i III. Genotipovi klastera I pokazali su višu prosječnu performancu a nižu u klasteru III za važnije značajke uključujući prinos mahune po biljci.

Ključne riječi: genetska varijabilnost, heritabilnost, prinos, dugi grah

\section{INTRODUCTION}

Yard long bean (Vigna unguiculata L.) also called 'Barboti' is one of the most important and popular legume vegetables in Bangladesh. It is widely grown throughout Asia. However, the production is much lower in Bangladesh (3.64 t/ha) as compared to other Asian countries (Huque et al., 2012). It is grown for its young leaves, immature pods and mature dry seeds (Hazra et al., 2007; Hall et al., 2003). It is a short duration crop and become an important component of sustainable agriculture. Like other legume vegetables, yard long bean is also nutritionally rich. It contains high percentage of digestible protein (23.52-26.27\%), vitamin A, thiamin, riboflavin, calcium, phosphorus, sodium, potassium, magnesium (Anon. 2006; Ano and Ubochi, 2008). Besides, the immature pods of yard long bean is a good source of vitamins $\mathrm{C}$, folate and micronutrients $102.69-120.02 \mathrm{mg} / \mathrm{kg}$ of iron, $32.58-36.66 \mathrm{mg} / \mathrm{kg}$ of zinc, 
Zakia Sultana et. al.: Genetic variability and yield components of yard long bean (Vigna unguiculata var. sesquipedalis L.)

$2.92-3.34 \mathrm{mg} / \mathrm{kg}$ of manganese and $0.33-0.57 \mathrm{mg} / \mathrm{kg}$ of cobalt (Vaughan and Geissler, 2009). The immature tender pods and fresh seeds of yard long bean are used to prepare delicious dishes. In addition, its dry seeds are also preferred in different part of the world (Nielsen et al., 1997; Timko and Singh, 2008). Therefore, this nutritionally rich vegetable can be used to improve the diet of the people in Bangladesh.

Yield of yard long bean is a complex and highly variable which is connected to a number of component (Ullah et al., 2011). Thus, selection of appropriate cultivars/breeding lines is a key step for commercial cultivation of this vegetable. The information on genetic variability, character association between yield and its contributing traits is essential for improvement of yield via the conventional breeding program (Fraser and Eaton, 1983). Cause-effect analysis also offers an effective means of partitioning the correlation coefficients into direct and indirect effects of the components on yield which enable us to devise the crop improvement program logically (Rao et al., 1997). Further, the genetic distance between pair of genotypes offers the basis for understanding the structure of the diversity of any intra-species population. It constructs an all-to-all matrix to describe the distance between each sequence pair of genotypes; thereby guiding plant breeder in their selection procedure (Adewale et al., 2011). The multivariate analysis is a valuable tool for selecting parents for hybridization program (Hazra et al., 1992; Rahim et al., 2010). Besides, the genetic diversity or genetic similarity could help to get long term selection gain in plants (Chowdhury et al., 2002). Therefore, evaluation of genetic divergence in the available germplasm of the crop is crucial to know the source of genes for a particular character (Tomooka, 1991).

Yard long bean grown in a summer specifically 'Kharif' season in our country, when there is a scanty of different vegetable crops. Regardless, until now, there is no commercial cultivar of yard long bean with higher yield in Bangladesh. In addition, there is a lack of proper breeding strategies for the genetic improvement of this nutritious vegetable. Therefore, the present study was planned to characterize the important traits related to yield and quality and to select genetically diverse parents for the hybridization program. 
Zakia Sultana et. al.: Genetic variability and yield components of yard long bean (Vigna unguiculata var. sesquipedalis L.)

\section{MATERIAL AND METHODS}

\section{Plant Materials and Experimental Design}

Seven yard long bean genotypes was used in this study (Table 1, Fig. 1). The seeds of these genotypes were collected from local seed market, Dhaka, Bangladesh. The experiment was conducted at the Sher-e-Bangla Agricultural University (SAU) experimental farm on randomized complete bock design (RCBD) with 3 replications. Seed of each genotype were directly sown in field with a spacing of $50 \mathrm{~cm} \times 30 \mathrm{~cm}$ in three replications. The plants were trained onto an inverted ' $\mathrm{V}$ ' structure. The standard fertilizer doses like Urea, TSP, MP was applied in field at the rate of $55,160,160 \mathrm{Kg} / \mathrm{ha}$, respectively. and cultural management were done to keep a healthy plant growth. The harvesting was done separately for each genotype when $80 \%$ of plants was mature.

Table 1 List of yard long bean genotypes used in this study

Tablica 1. Popis genotipova graha korištenih u ovoj studiji

\begin{tabular}{|c|l|c|}
\hline Genotype & Pod color & Accession number \\
\hline G1 & Green & SAU/YLB/0001 \\
\hline G2 & Deep Green & SAU/YLB/0002 \\
\hline G3 & Red & SAU/YLB/0003 \\
\hline G4 & White & SAU/YLB/0004 \\
\hline G5 & Red & SAU/YLB/0005 \\
\hline G6 & Red & SAU/YLB/0009 \\
\hline G7 & Deep Green & SAU/YLB/00010 \\
\hline
\end{tabular}


Zakia Sultana et. al.: Genetic variability and yield components of yard long bean (Vigna unguiculata var. sesquipedalis L.)

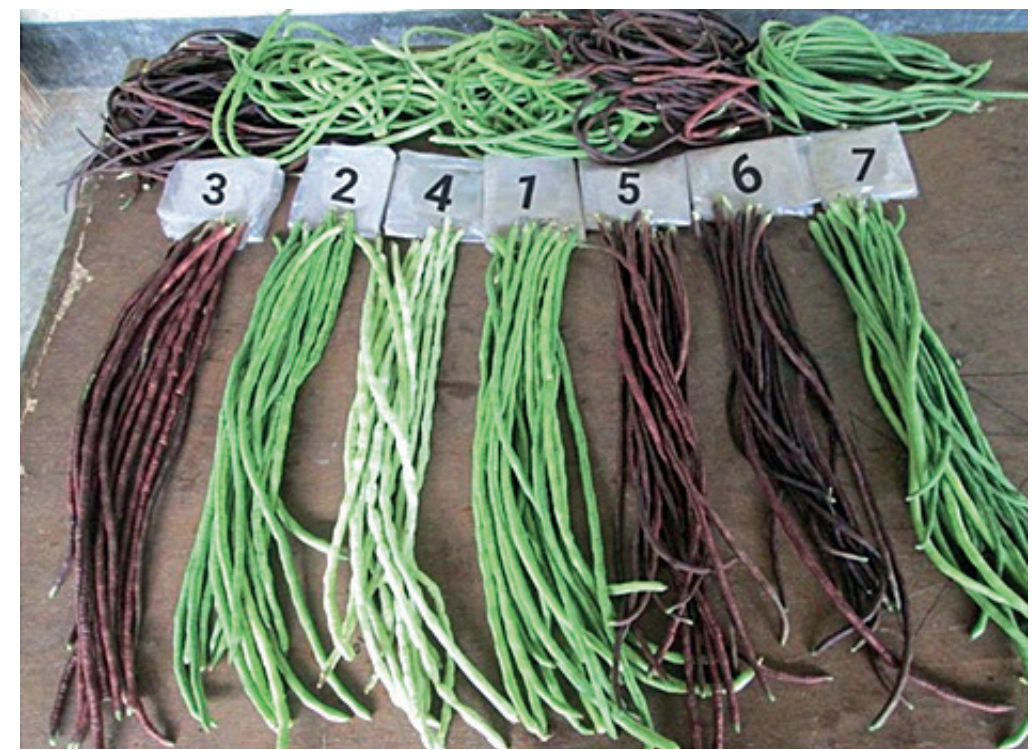

Fig. 1 Different genotypes used in the study

Slika 1. Različiti genotipovi korišteni u istraživanju

\section{Data collection}

The data were recorded on five randomly selected plants for days to first flowering, days to $50 \%$ flowering, days to marketable harvest, pod length $(\mathrm{cm})$, pod diameter $(\mathrm{cm})$, number of pod per plant, average pod weight $(\mathrm{g})$, number of seed per pod, 100-seed weight (gm) and pod yield per plant $(\mathrm{g})$.

\section{Statistical analysis}

The collected data were further subjected to statistical analysis. The phenotypic and genotypic variances were determined with the formula suggested by Johnson et al. (1955) while heritability and genetic advance were measured as per Singh and Chaudhury (1985). Genotypic co-efficient of variation $(\mathrm{GCV})$ and phenotypic co-efficient of variation (PCV) were determined according to Burton (1952). Correlation coefficient and path coefficient analysis were performed as per Miller et al. (1958) and Dewey and Lu (1959), respectively. The heatmaps were generated via online heatmapper tool (www2.heatmapper.ca). 
Zakia Sultana et. al.: Genetic variability and yield components of yard long bean (Vigna unguiculata var. sesquipedalis L.)

\section{RESULTS AND DISCUSSION}

\section{Genetic variability}

The analysis of variance showed that there is a significant difference for different traits among the studied yard long bean genotypes (Table 2). Thus, suggesting the possibility of genetic improvement of this vegetable for studied traits. The results showed that the phenotypic variance $\left(\sigma^{2} p\right)$ was higher than the genotypic variance $\left(\sigma^{2} g\right)$ for all the traits (Table 2) suggesting the existence of environmental effect on the phenotypic expression of traits. Rahim et al. (2010) reported the similar results in mungbean (Vigna radiate L. Wilczek). Likewise, the genotypic coefficient of variation (GCV) was higher the phenotypic coefficient of variation (PCV) for studied traits. The high GCV and PCV were found for number of pods per plant, pod yield per plant, pod diameter, 100-seed weight and pod length. Vidya et al. (2002) reported the similar results for number of pods per plant, pod weight and pod yield per plant of yard long bean. Shanko et al. (2014) also reported the identical results for number of pods per plant, 100-seed weight, and yield per plant in cowpea (Vigna unguiculata L. Walp). The higher $\sigma^{2}$ g was found for pod length and pod yield per plant suggesting the prevalence of higher degree of genetic variability for these traits. The high broad sense heritability was found for all the traits except seeds per pod. Shanko et al. (2014) reported high heritability for yield per plant, pods per plant, and 100-seed weight. The heritability estimates together with genetic advance are considered as more reliable for phenotypic selection (Johnson et al., 1955). The high heritability with high genetic advance in percentage of mean was found for pods per plant and pod yield per plant suggesting that these traits are controlled by the additive gene action and phenotypic selection could be effective. Vidya et al. (2014), Shanko et al. (2014), Vavilapalli and Celine (2014) reported a similar results for pod numbers, weight, and yield per plant. Rahim et al. (2010) also found a similar result for pods per plant and seed yield per plant in mungbean. 
Zakia Sultana et. al.: Genetic variability and yield components of yard long bean (Vigna unguiculata var. sesquipedalis L.)

Table 2 Estimation of genetic parameters for 10 traits among yard long bean genotypes

Tablica 2. Procjena genetičkih parametara za 10 svojstava među genotipovima dugačkog graha

\begin{tabular}{|c|c|c|c|c|c|c|c|c|c|}
\hline Traits & 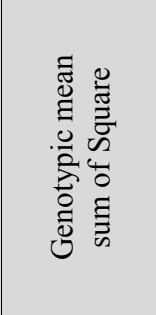 & 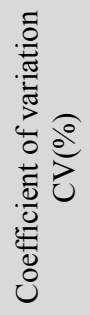 & 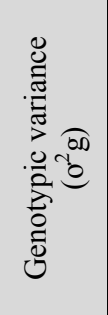 & 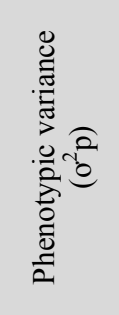 & 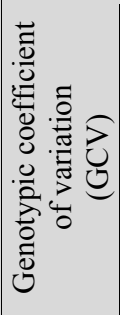 & 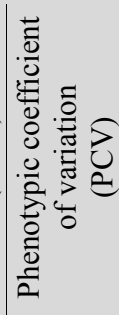 & 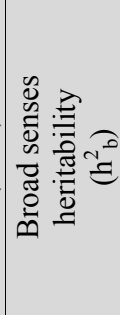 & 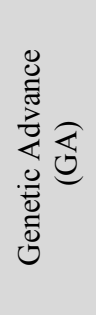 & 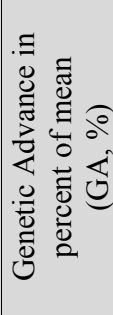 \\
\hline $\begin{array}{l}\text { Days to first } \\
\text { flowering }\end{array}$ & $5.05 * *$ & 1.98 & 1.51 & 2.03 & 3.35 & 3.89 & 74.22 & 2.18 & 5.95 \\
\hline $\begin{array}{l}\text { Days to } 50 \% \\
\text { flowering }\end{array}$ & $6.97 * *$ & 1.87 & 2.11 & 2.75 & 3.41 & 3.89 & 76.88 & 2.62 & 6.16 \\
\hline $\begin{array}{l}\text { Days to } \\
\text { marketable } \\
\text { harvest }\end{array}$ & $8.49 * *$ & 1.39 & 2.58 & 3.33 & 2.57 & 2.93 & 77.38 & 2.91 & 4.67 \\
\hline $\begin{array}{l}\text { Pod length } \\
(\mathrm{cm})\end{array}$ & $125.32 * *$ & 9.24 & 33.41 & 58.51 & 10.66 & 14.11 & 57.10 & 9.00 & 16.60 \\
\hline Pod diameter & $0.03 * *$ & 11.79 & 0.01 & 0.01 & 15.85 & 19.75 & 64.39 & 0.15 & 26.20 \\
\hline $\begin{array}{l}\text { Number of } \\
\text { pod per plant }\end{array}$ & $12.55^{* *}$ & 5.10 & 4.14 & 4.28 & 28.00 & 28.46 & 96.78 & 4.12 & 56.74 \\
\hline $\begin{array}{l}\text { Average Pod } \\
\text { weight }(\mathrm{g})\end{array}$ & $4.63 * *$ & 5.88 & 1.30 & 2.03 & 7.80 & 9.77 & 63.76 & 1.87 & 12.84 \\
\hline $\begin{array}{l}\text { Number of } \\
\text { seed per pod }\end{array}$ & $2.62 *$ & 4.50 & 0.60 & 1.42 & 3.84 & 5.91 & 42.20 & 1.04 & 5.14 \\
\hline $\begin{array}{l}100 \text {-seed } \\
\text { weight }(\mathrm{g})\end{array}$ & $6.41 * *$ & 3.69 & 2.07 & 2.27 & 11.88 & 12.44 & 91.21 & 2.83 & 23.37 \\
\hline $\begin{array}{l}\text { Pod yield per } \\
\text { plant }(\mathrm{g})\end{array}$ & $2830.36 * *$ & 9.28 & 909.80 & 1010.77 & 27.87 & 29.37 & 90.01 & 58.95 & 54.46 \\
\hline
\end{tabular}


Zakia Sultana et. al.: Genetic variability and yield components of yard long bean (Vigna unguiculata var. sesquipedalis L.)

\section{Trait association}

The genotypic and phenotypic correlation coefficients among 10 yield and it's contributing traits are shown in Table 3 and Figure 2. The genotypic correlations were higher than the phenotypic correlation coefficients for all the traits suggesting the association of between traits is primarily due to genetic effects. Pod yield showed a highly significant positive correlation with number of pods per plant and number of seeds per pod at both the genotypic and phenotypic level indicating a high degree of association between these traits. Vidya and Oommen (2006) described similar result for number of pods per plant and number of seeds per pod in yard long bean. Rahim et al. (2010) also reported similar results for number of pods per plant and number of seeds per pod in mungbean. Hakim (2008) reported a significant positive correlation of yield with number of pods per plant.

The path coefficient analysis showed that days to marketable harvest had maximum positive direct effect (Table 4). Nonetheless, days to marketable harvest was negatively correlated with pod yield. A second height positive direct effect was found in number of pods per plant (Table 4). Moreover, number of pods per plant and number of seeds per pod exhibited positive indirect effect to pod yield via days to $50 \%$ flowering, pod length, pod diameter, number of seeds per pod and 100-seed weight (Table 4). The result reveals a true relationship between traits and direct selection could be beneficial for the yield improvement in yard long bean. The results is in agreement with the findings of previous reports (Lal et al., 2007; Udensi et al., 2012). The residual effect was 0.421 which indicated that there was influence of some other attributes like environment (approx. 42.1\%) on pod yield. 
Zakia Sultana et. al.: Genetic variability and yield components of yard long bean (Vigna unguiculata var. sesquipedalis L.)

Table 3 Genotypic $\left(r_{g}\right)$ and phenotype $\left(r_{p}\right)$ correlation coefficients among different traits of yard long bean genotype.

Tablica 3. Genotipska (rg) i fenotipska (rp) korelacija između različitih osobina genotipa dugačkoga graha

\begin{tabular}{|c|c|c|c|c|c|c|c|c|c|c|}
\hline Traits & & $\mathrm{D} 50 \mathrm{~F}$ & DMH & PL & PD & NPP & APW & NSP & HSW & PYP \\
\hline \multirow{2}{*}{ DFF } & $r_{g}$ & $0.954 * *$ & $0.992 * *$ & $0.638 * *$ & 0.242 & -0.365 & $0.572 * *$ & $-0.455^{*}$ & $0.583^{* *}$ & -0.293 \\
\hline & $\mathrm{r}_{\mathrm{p}}$ & $0.833^{* *}$ & $0.869 * *$ & 0.356 & 0.051 & -0.291 & 0.351 & -0.377 & $0.489^{*}$ & -0.256 \\
\hline \multirow{2}{*}{$\mathrm{D} 50 \% \mathrm{~F}$} & $\mathrm{r}_{\mathrm{g}}$ & & $0.978 * *$ & $0.562 * *$ & 0.229 & $-0.506^{*}$ & 0.316 & $-0.493^{*}$ & $0.449^{*}$ & $-0.483^{*}$ \\
\hline & $r_{p}$ & & $0.976^{* *}$ & 0.369 & 0.039 & $-0.439^{*}$ & 0.275 & -0.403 & 0.423 & -0.429 \\
\hline \multirow{2}{*}{$\mathrm{DMH}$} & $r_{g}$ & & & $0.657 * *$ & 0.298 & $-0.590 * *$ & $0.450^{*}$ & $-0.635 * *$ & $0.602 * *$ & $-0.537^{*}$ \\
\hline & $\mathrm{r}_{\mathrm{p}}$ & & & $0.555^{* *}$ & 0.082 & $-0.516^{*}$ & 0.312 & $-0.514 *$ & $0.555^{* *}$ & $-0.503 *$ \\
\hline \multirow{2}{*}{ PL } & $r_{g}$ & & & & -0.061 & -0.330 & 0.266 & $-0.477^{*}$ & $0.524 *$ & -0.307 \\
\hline & $\mathrm{r}_{\mathrm{p}}$ & & & & -0.043 & -0.273 & 0.283 & -0.303 & $0.441 *$ & -0.154 \\
\hline \multirow{2}{*}{ PD } & $r_{g}$ & & & & & $-0.604 * *$ & $0.829 * *$ & $-0.885 * *$ & $0.465^{*}$ & $-0.645^{* *}$ \\
\hline & $r_{p}$ & & & & & $-0.489^{*}$ & $0.623^{* *}$ & $-0.434 *$ & 0.283 & $-0.480^{*}$ \\
\hline \multirow{2}{*}{ NPP } & $r_{g}$ & & & & & & -0.259 & $0.976^{* *}$ & $-0.552 * *$ & $0.974^{* *}$ \\
\hline & $\mathrm{r}_{\mathrm{p}}$ & & & & & & -0.204 & $0.767 * *$ & $-0.512 *$ & $0.970^{* *}$ \\
\hline \multirow{2}{*}{ APW } & $\mathrm{r}_{\mathrm{g}}$ & & & & & & & $-0.695 * *$ & $0.800 * *$ & -0.268 \\
\hline & $r_{p}$ & & & & & & & -0.249 & $0.577 * *$ & -0.119 \\
\hline \multirow{2}{*}{ NSP } & $r_{g}$ & & & & & & & & $-0.857 * *$ & $0.932^{* *}$ \\
\hline & $r_{p}$ & & & & & & & & $-0.552 * *$ & $0.767^{* *}$ \\
\hline \multirow{2}{*}{ HSW } & $r_{g}$ & & & & & & & & & $-0.500 *$ \\
\hline & $\mathrm{r}_{\mathrm{p}}$ & & & & & & & & & $-0.439 *$ \\
\hline
\end{tabular}

$* *=$ Significant at $1 \%, *=$ Significant at $5 \%, \mathrm{DFF}=$ Days to first flowering, D50F $=$ Days to $50 \%$ flowering, $\mathrm{DMH}=$ Days to marketable harvest, $\mathrm{PL}=$ Pod length $(\mathrm{cm}), \mathrm{PD}=$ Pod diameter, NPP $=$ Number of pod per plant, APW $=$ Average Pod weight $(\mathrm{g}), \mathrm{NSP}=$ Number of seed per pod, HSW $=100$ seed weight $(\mathrm{g})$, $\mathrm{PYP}=$ Pod yield per plant $(\mathrm{g})$. 
Zakia Sultana et. al.: Genetic variability and yield components of yard long bean (Vigna unguiculata var. sesquipedalis L.)

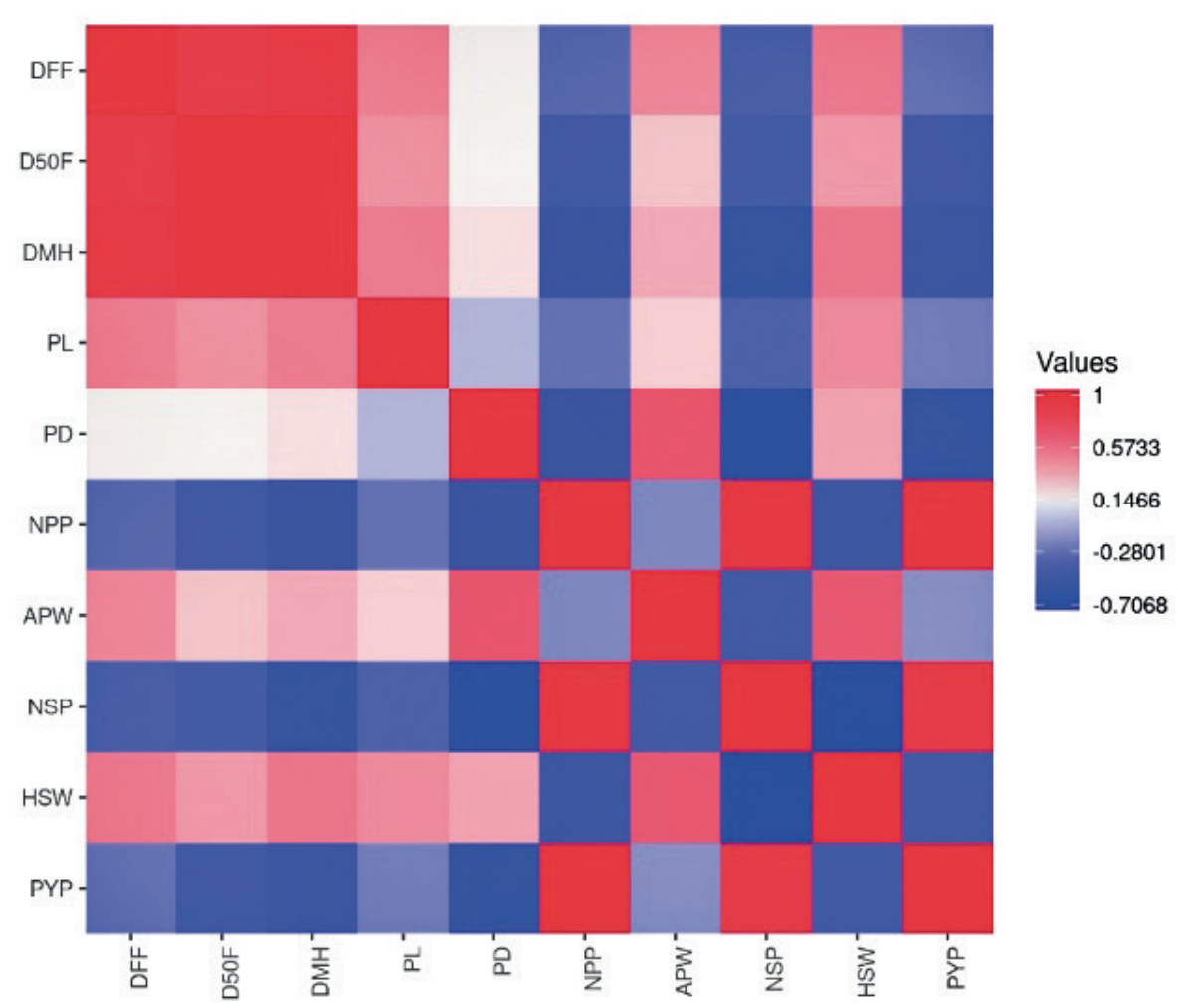

Figure 2 Correlation matrix showing correlation between different traits of yard long bean

Slika 2. Prikaz korelacije koja pokazuje povezanost različitih osobina dugačkog graha

The red and blues colors in the legend indicates highest and lowest values, respectively. $50 \mathrm{~F}=$ Days to $50 \%$ flowering, $\mathrm{DM}=$ Days to $80 \%$ maturity, $\mathrm{PH}=$ Plant height $(\mathrm{cm}), \mathrm{LMR}=$ Length of main 
Zakia Sultana et. al.: Genetic variability and yield components of yard long bean (Vigna unguiculata var. sesquipedalis L.)

Table 4 Direct (bold) and indirect effects of different traits at genotypic level on yield of yard long bean

Tablica 4. Izravni i neizravni učinci različitih svojstava na genotipskoj razini na prinos dugačkog graha

\begin{tabular}{|c|c|c|c|c|c|c|c|c|c|c|}
\hline & \multicolumn{7}{|c|}{ Effect via } & \multirow{2}{*}{ r (Yield) } \\
\cline { 2 - 10 } & DFF & $\mathbf{D 5 0 F}$ & DMH & PL & PD & NPP & APW & NSP & HSW & \\
\hline DFF & $\mathbf{0 . 5 0 2}$ & -1.471 & 1.259 & -0.170 & -0.086 & -0.219 & 0.106 & -0.065 & -0.149 & -0.293 \\
\hline D50\%F & 0.479 & $\mathbf{- 1 . 5 4 2}$ & 1.241 & -0.149 & -0.081 & -0.304 & 0.058 & -0.070 & -0.114 & $-0.483^{*}$ \\
\hline DMH & 0.498 & -1.508 & $\mathbf{1 . 2 6 9}$ & -0.175 & -0.105 & -0.354 & 0.083 & -0.091 & -0.154 & $-0.537^{*}$ \\
\hline PL & 0.320 & -0.867 & 0.834 & $\mathbf{- 0 . 2 6 6}$ & 0.022 & -0.198 & 0.049 & -0.068 & -0.134 & -0.307 \\
\hline PD & 0.121 & -0.353 & 0.378 & 0.016 & $\mathbf{- 0 . 3 5 4}$ & -0.362 & 0.153 & -0.127 & -0.119 & $-0.645^{* *}$ \\
\hline NPP & -0.183 & 0.780 & -0.749 & 0.088 & 0.214 & $\mathbf{0 . 6 0 0}$ & -0.048 & 0.162 & 0.141 & $0.974 * *$ \\
\hline APW & 0.287 & -0.487 & 0.571 & -0.071 & -0.293 & -0.155 & $\mathbf{0 . 1 8 5}$ & -0.099 & -0.204 & -0.268 \\
\hline NSP & -0.228 & 0.760 & -0.806 & 0.127 & 0.313 & 0.682 & -0.129 & $\mathbf{0 . 1 4 3}$ & 0.219 & $0.932^{* *}$ \\
\hline HSW & 0.293 & -0.692 & 0.764 & -0.139 & -0.165 & -0.331 & 0.148 & -0.123 & $\mathbf{- 0 . 2 5 5}$ & $-0.500^{*}$ \\
\hline
\end{tabular}

Residual effect $(\mathrm{R})=0.421, * *=$ Significant at $1 \%, *=$ Significant at $5 \%$, DFF $=$ Days to first flowering, $\mathrm{D} 50 \mathrm{~F}=$ Days to $50 \%$ flowering, $\mathrm{DMH}=$ Days to marketable harvest, $\mathrm{PL}=$ Pod length $(\mathrm{cm}), \mathrm{PD}=\mathrm{Pod}$ diameter, $\mathrm{NPP}=$ Number of pod per plant, APW $=$ Average Pod weight $(\mathrm{g})$, NSP $=$ Number of seed per pod, $\mathrm{HSW}=100$ seed weight $(\mathrm{g}), \mathrm{PYP}=$ Pod yield per plant $(\mathrm{g})$.

\section{Selection of superior genotypes}

We further performed a cluster analysis using online tool (http://www2.heatmapper.ca) and the genotypes were grouped into three clusters (Table 5 and Figure 3). The maximum four genotypes were included in cluster III while only one for cluster I (Table 5). The genotypes belong to cluster I exhibited better performance for number of pod per plant, number of seed per pod and pod yield per plant (Table 6). On the other hand, the genotypes of cluster III showed better performance for days to first flowering, days to $50 \%$ flowering, days to marketable harvest, pod length, pod diameter, average pod weight and 100-seed weight. Furthermore, the genotypes of cluster III were distantly related among other clusters (Figure 4). 
Zakia Sultana et. al.: Genetic variability and yield components of yard long bean (Vigna unguiculata var. sesquipedalis L.)

Table 5 Distribution of yard long bean genotypes into different clusters

Tablica 5. Raspodjela genotipova dugačkog graha u različite skupine

\begin{tabular}{|c|l|}
\hline Cluster & \multicolumn{1}{c|}{ Genotypes } \\
\hline I & G1 (SAU/YLB/0001) \\
\hline II & G2 (SAU/YLB/0002), G5 (SAU/YLB/0005) \\
\hline III & $\begin{array}{l}\text { G3 (SAU/YLB/0003), G4(SAU/YLB/0004), } \\
\text { G6 (SAU/YLB/0009), G7 (SAU/YLB/00010) }\end{array}$ \\
\hline
\end{tabular}

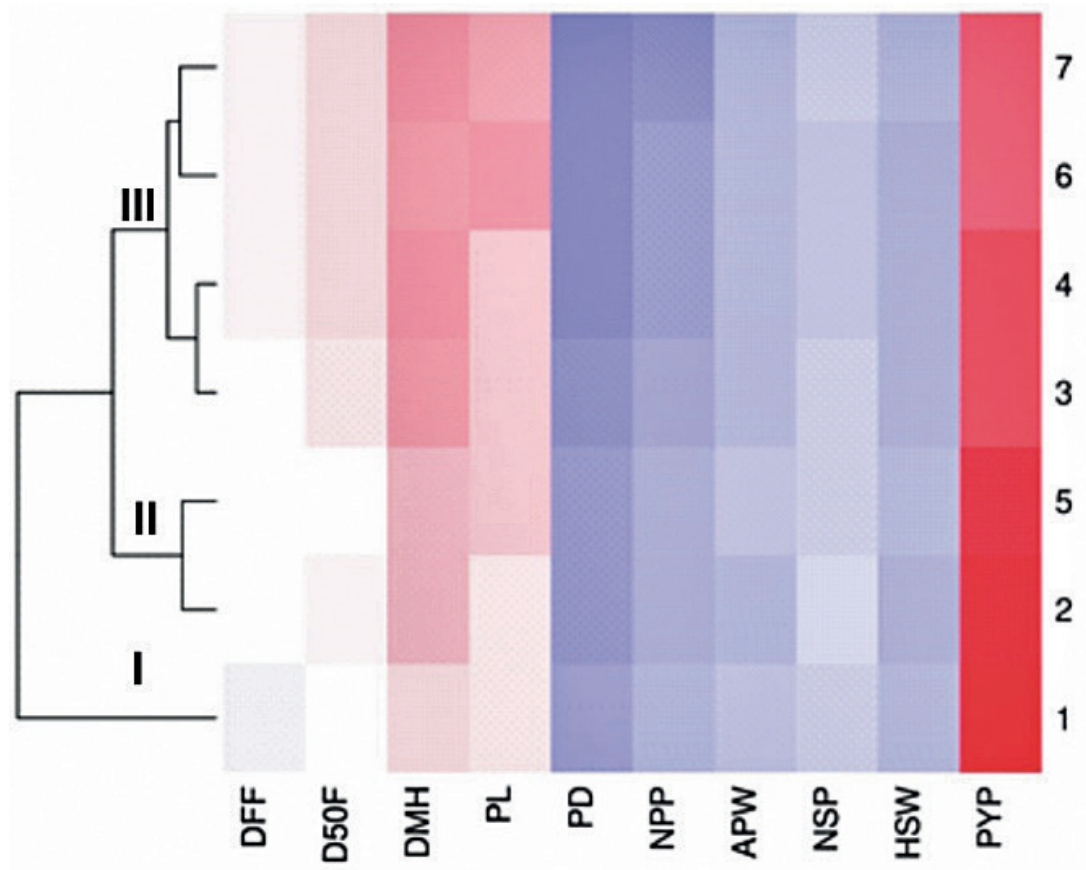

Figure 3 Heatmap representation of yard long bean genotypes into three clusters.

The red and blues colors in the legend indicates highest and lowest values, respectively. $D F F=$ Days to first flowering, D50F = Days to 50\% flowering, DMH = Days to marketable harvest, $P L=$ Pod length (cm), $P D=$ Pod diameter, $N P P=$ Number of pod per plant, APW = Average Pod weight (g), NSP = Number of seed per pod, $H S W=100$ seed weight $(g), P Y P=$ Pod yield per plant $(g)$. 
Zakia Sultana et. al.: Genetic variability and yield components of yard long bean (Vigna unguiculata var. sesquipedalis L.)

Table 6. Cluster mean for yield and yield related characters in yard long bean varieties

\begin{tabular}{|l|c|c|c|}
\hline \multicolumn{1}{|c|}{ Traits } & I & II & III \\
\hline Days to 1st flowering & 36.67 & 35.50 & 37.17 \\
\hline Days to 50\% flowering & 42.00 & 41.33 & 43.33 \\
\hline Days to marketable harvest & 61.67 & 60.83 & 63.33 \\
\hline Pod length (cm) & 53.21 & 52.42 & 55.35 \\
\hline Pod diameter (cm) & 0.41 & 0.60 & 0.60 \\
\hline Number of pod per plant & 10.99 & 8.31 & 5.81 \\
\hline Average pod weight (g) & 14.18 & 14.46 & 14.77 \\
\hline Number of seed per pod & 21.70 & 20.65 & 19.53 \\
\hline 100 seed weight (gm) & 11.86 & 10.74 & 12.86 \\
\hline Pod yield per plant (g) & 166.67 & 121.27 & 87.12 \\
\hline
\end{tabular}

The red and blues colors in the legend indicates highest and lowest values, respectively.

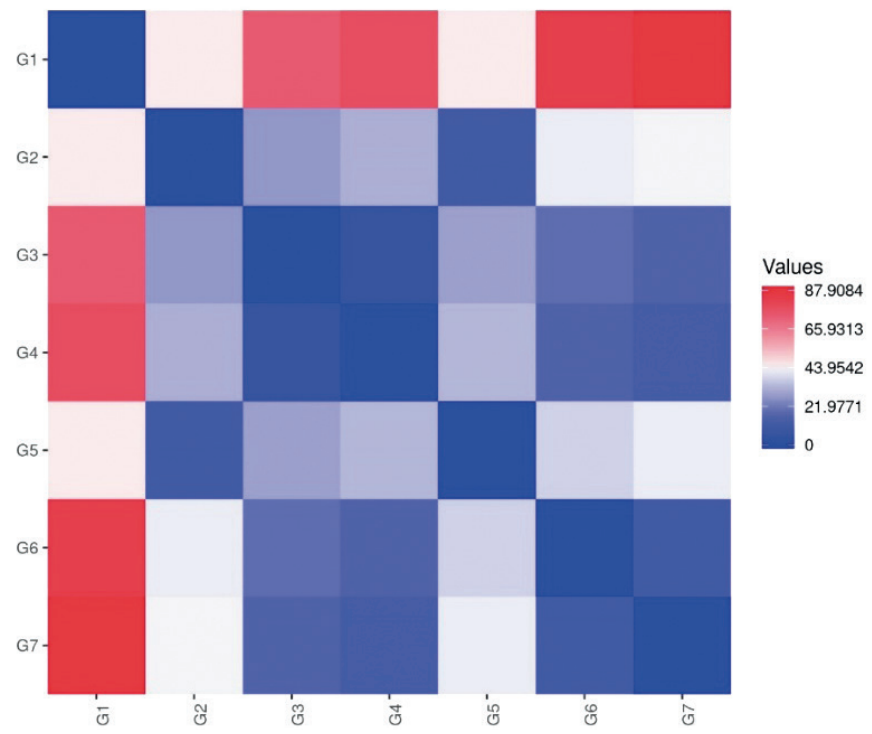

Figure 4 Distance matrix represents the pairwise comparisons between yard long bean genotypes. The red and blues colors in the legend indicates highest and lowest values, respectively. 
Zakia Sultana et. al.: Genetic variability and yield components of yard long bean (Vigna unguiculata var. sesquipedalis L.)

\section{CONCLUSIONS}

Based on genetic parameters, trait association, agronomic performance, genotypic distance, it can be concluded that the genotypes belong to the cluster I and III might product high heterosis. Cluster I comprises genotypes with higher cluster means for number of pods per plant, number of seeds per pod as well as pod yield per plant while cluster III includes genotypes with days to $50 \%$ flowering, days to marketable harvest, pod length, average pod weight and 100-seed weight. Therefore, genotypes belongs to these clusters might be utilized for hybridization program to develop new yard long bean cultivars with higher yield.

\section{ACKNOWLEDGEMENTS}

We thank SAURES, Sher-e-Bangla Agricultural University (SAU), Dhaka1207, Bangladesh for providing experimental field and other supports to this research.

\section{REFERENCES}

1. Adewale, B.D., Adeigbe, O.O., Aremu, C.O. (2011). Genetic distance and diversity among some cowpea (Vigna unguiculata L. Walp) genotypes. Intl. Res. Plant Sci. 1: 9-14.

2. Ano, A.O. and Ubochi, C,I. (2008). Nutrient composition of climbing and prostrate vegetable cowpea accessions. African J. Biotech. 7: 3795-3798.

3. Anonymous. (2006) Lost Crops of Africa, Vol. II: Vegetables. The National Academies Press, Washington, DC. 2006; pp. 226.

4. Burton, G.W. (1952). Quantitative inheritance in grass pea. Proc. of the 6th Int. Grassland Cong. Pennsylvania, USA. pp. 277-283.

5. Chowdhury, M.A., Vandenberg, V. and Warkentin, T. (2002). Cultivar identification and genetic relationship among selected breeding lines and cultivars in chick pea (Cicer arietinum L). Euphytica. 127: 317-325

6. Dewey, D.R. and Lu, K. (1959). A correlation and path-coefficient analysis of components of crested wheatgrass seed production. Agron. J. 51: 515-518.

7. Fraser, J. and Eaton, G.W. (1983). Application of yield component analysis to crop research. Field Crop Abst. 36: 787-797. 
Zakia Sultana et. al.: Genetic variability and yield components of yard long bean (Vigna unguiculata var. sesquipedalis L.)

8. Hakim, L. (2008) Variability and correlation of agronomic characters of mungbean germplasm and their utilization for variety improvement program. Indonesian J. Agril. Sci. 9: 24-28.

9. Hall, E.A., Cissé, N., Thiaw, S., Elawad, H.O.A., Ehlers, J.D., Ismail, A.M., Fery, R.L., Roberts, P.A., Kitch, L.W., Murdock, L.L., Boukar, O., Phillips, R.D. and Mc Watters, K.H. (2003). Development of cowpea cultivars and germplasm by the Bean/Cowpea CRSP. Field Crops Res. 82: 103-134.

10. Hazra, P., Chattopadhaya, A., Dasgupta, T., Kar, N., Das, P.K. and Som, M.G. (2007). Breeding strategy for improving plant type, pod yield and protein content in vegetable cowpea (Vigna unguiculata). Acta Hort. 752: 275-280.

11. Hazra, P., Som, M.G., Das, P.K. (1992). Selection of parents for vegetable cowpea breeding by multivariate analysis. Veg. Sci. 19: 166-173.

12. Huque, A.M., Hossain, M.K., Alam, N., Hasanuzzaman, M. and Biswas, B.K. (2012). Genetic divergence in yard long bean (Vigna unguiculata (L.) Walp. ssp. sesquipedalis Verdc.). Bangladesh J. Bot. 41: 61-69.

13. Johnson, H.W., Robinson, H.F. and Comstoc. R. (1955). Estimates of genetic and environmental variability in soybeans. Agron. J. 47: 314-318.

14. Lal, H., Rai, M., Karan, S., Verma, A. and Ram, D. (2007). Multivariate hierarchical clustering of cowpea germplasm [Vigna unguiculata (L.) Walp.]. Acta Hort. 752: 413-416.

15. Miller, P.A., Williams, J.C., Robinson, H.F., Comstock, R.E. (1958). Estimates of genotypic and environmental variances and covariances in upland cotton and their implications in selection. Agron. J. 50: 126-131.

16. Nielsen, S.S., Ohler, T.A. and Mitchell, C.A. (1997). Cowpea leaves for human consumption: production, utilization, and nutrient composition. In: Singh, B.B., Mohan Raj, D.R., Dashiell, K.E. and Jackai, L.E.N.(eds). Advances in Cowpea Research. Co-publication Intl Inst Tropical Agric (IITA) and Japan Intl Res Center Agric Sci (JIRCAS). Sayce, Devon, UK. pp. 326-332.

17. Rahim, M.A., Mia, A.A., Mahmud, F., Zeba, N. and Afrin, K.S. (2010). Genetic variability, character association and genetic divergence in mungbean (Vigna radiate L. Wilczek). Plant Omics J. 3(1): 1-6.

18. Rao, A., Khan, M.A., McNeilly, T. and Khan A.A. (1997). Cause and effect relations of yield and yield components in rice (Oryza sativa L.). J. Genet. Breed. 51: 1-5.

19. Shanko D, Andargie M, Zelleke H. (2014). Genetic variability and heritability of yield and related characters in cowpea (Vigna unguiculata L. Walp.). Research in Plant Biology, 2014; 4: 21-26. 
Zakia Sultana et. al.: Genetic variability and yield components of yard long bean (Vigna unguiculata var. sesquipedalis L.)

20. Singh, R.K. and Chaudhary, B.D. (1985). Biometrical methods in quantitative genetic analysis. Kalyani Publishers, New Delhi, India. p.56.

21. Timko, M.P. and Singh, B.B. (2008). Cowpea, a multifunctional legume. In: Moore, P.H. and Ming, R.(eds.). Genomics of tropical crop plants, department of biology, University of Virginia, Charlottesville, VA 22904 USA. pp. 227-258.

22. Tomooka, N. (1991). Genetic diversity and landrace differentiation of mungbean (Vigna radiata L.) Wilczek and evaluation of its wild relatives (The subgenus Ceratotropics) as breeding materials. Tech. Bull. Trop. Res. 28: 1-4.

23. Udensi, O., Ikpeme, E.V., Edu, E.A., Ekpe, D.E. (2012). Relationship studies in cowpea [Vigna unguiculata (L.) Walp] landraces grown under humid lowland condition. Intern. Agri Res. 7:33-45.

24. Ullah, M.Z., Hasan, M.J., Rahman, A.H.M.A. and Saki, AI. (2011). Genetic variability, character association and path analysis in Yard long bean. SAARC J. Agric. 9: 9-16.

25. Vaughan, J.G. and Geissler, C.A. (2009). The new oxford book of food plants. Oxford University Press Inc., p. 52.

26. Vavilapalli S., Celine VA. (2014). Genetic variability, heritability and genetic advance foryield and yield attributes in yard-long bean (Vigna unguiculata subsp. sesquipedalis [L.] Verde.). Bioinfolet. 11: 415-417.

27. Vidya, C., Oommen, S.K. and Kumar, V. (2006) Genetic variability and heritability of yield and related characters in yard-long bean. J. Trop. Agric. 40: 11-13.

28. Vidya, C., Sunny, K., Oommen, S.K. and Kumarv, V. (2002). Genetic variability and heritability of yield and related characters in yard long bean. J. Trop. Agric. 40: 11-13.

29. https://www2.heatmapper.ca

Author's addresses - Adrese autora:

Received - Primljeno

Zakia Sultana,

20.05.2020.

Nahid Ahmed,

Mohammad Saiful Islam,

Md. Abdur Rahim: Corresponding author: rahimgepb@sau.edu.bd

Department of Genetics and Plant Breeding, Faculty of Agriculture, Sher-e-Bangla Agricultural University, Dhaka-1207, Bangladesh 